\title{
Claystone formations in Germany: what we (don't) know about them and how we can change this
}

\author{
Bernhard Schuck and Tilo Kneuker \\ Federal Institute for Geosciences and Natural Resources (BGR), Stilleweg 2, 30655 Hannover, Germany \\ Correspondence: Bernhard Schuck (bernhard.schuck@bgr.de) \\ Published: 10 November 2021
}

\begin{abstract}
Deep geological formations are considered for safe long-term disposal of high-level radioactive waste. Such a repository would be requested to prevent radionuclides from entering the biosphere for a period of 1 million years (StandAG, 2017). Consequently, a holistic characterization including lithological, mineralogical, geochemical, hydrological, structural and geomechanical properties of any potential repository-hosting rock formation is required.

Nine claystone formations have been identified as "sub-areas" within the German site-selection procedure (BGE, 2020). The area covered by these formations comprises about half of the total area considered as being qualified for further exploration. However, despite its relevance to act as a geological barrier for, e.g. hydrocarbons or radionuclides, the characterization of clay-rich formations at depths exceeding $300 \mathrm{~m}$ in Germany has attained substantially less attention than economically more relevant units hosted by, e.g. sandstones or rock salt, which have been intensively explored.

The BGR project BASTION aims at contributing to characterizing these claystone formations and emphasizes properties relevant to host a repository for nuclear waste. Investigations comprise (micro)structural/petrographic, mineralogical, geochemical, geophysical, hydraulic and thermomechanical analyses.

In project phase I (2013-2019), claystones deposited in Northern Germany during the Lower Cretaceous were studied. These rocks belong to the fourth largest sub-area hosting claystones. Two of the main foci were to explore variations in lithology, mineralogy and geochemistry, and to identify deformation mechanisms (natural and artificial) by microstructural analyses. Although rocks appeared to be quite homogeneous on the 10-100 $\mathrm{m}$ scale, the results revealed distinct structural and sedimentary heterogeneities on the meter scale affecting fracture density.

Another sub-area located in Southern Germany hosts the Opalinus Clay Formation (OPA). This up to $150 \mathrm{~m}$ thick claystone formation was deposited during the Middle Jurassic (Franz and Nitsch, 2009). Owing to its selfsealing capacity and ability to retain fluids, it is supposed to host the nuclear waste repository of Switzerland (Bossart et al., 2017). The OPA is quite well understood in terms of its lithology and (bio)stratigraphy, and there have been mineralogical, hydrological and petrophysical analyses, mostly documented in university theses a few decades old and sometimes difficult to access. However, it is questionable to what extent these investigations reflect the situation at depths relevant for the site-selection procedure. Well-documented data on the OPA and its properties relevant for nuclear waste disposal are available via the Swiss site-selection procedure (Bossart et al., 2017). However, as there remain substantial questions regarding the nature of the German portions of the OPA (e.g. spatial distribution of lithology, mineralogy, microstructures) at depths greater than a few decameters, it is unclear to what degree insights obtained in the Swiss site-selection procedure also account for Germany. Therefore, phase II of BASTION, which began in 2020, aims to use the multidisciplinary approach developed during phase I to characterize properties of the OPA relevant for the save long-term disposal of nuclear waste by identifying and quantifying structural and rheological heterogeneities. This will constitute important input for numerical models in any long-term safety assessment.
\end{abstract}

Kurzfassung. Für die sichere Langzeitlagerung hochradioaktiver Abfälle werden tiefe geologische Formationen in Betracht gezogen. Ein solches Endlager soll verhindern, dass in den nächsten 1 Million Jahren Ra- 
dionuklide in die Biosphäre gelangen (StandAG, 2017). Folglich ist eine vollständige Charakterisierung einschließlich lithologischer, mineralogischer, geochemischer, hydrologischer, struktureller und geomechanischer Eigenschaften jeder potenziellen Gesteinsformation, die ein Endlager beherbergen könnte, erforderlich.

Im Rahmen des deutschen Standortauswahlverfahrens wurden neun Tonsteinformationen als "Teilgebiete“ identifiziert (BGE, 2020). Die Fläche dieser Teilgebiete umfasst etwa die Hälfte der für die weitere Erkundung in Frage kommenden Gesamtfläche. Trotz ihrer Bedeutung als geologische Barriere, beispielsweise für Kohlenwasserstoffe oder Radionuklide, hat die Charakterisierung tonreicher Formationen in Tiefen von mehr als $300 \mathrm{~m}$ in Deutschland deutlich weniger Aufmerksamkeit erlangt als wirtschaftlich relevantere Lithologien wie z. B. Sandstein oder Steinsalz, die intensiv erkundet worden sind.

Ziel des BGR-Projekts BASTION ist es, einen Beitrag zur Charakterisierung dieser Tonsteinformationen zu leisten. Dabei liegt der Schwerpunkt auf Eigenschaften, die für ein Endlager für nukleare Abfälle relevant sind. Die Untersuchungen umfassen (mikro-)strukturelle/petrographische, mineralogische, geochemische, geophysikalische, hydraulische und thermo-mechanische Analysen.

In der Projektphase I (2013-2019) wurden Tonsteine untersucht, die in Norddeutschland in der Unterkreide abgelagert wurden. Diese Gesteine gehören zum viertgrößten Teilgebiet mit Tonstein. Zwei der Hauptschwerpunkte waren die Erforschung von Variationen in Bezug auf Lithologie, Mineralogie und Geochemie sowie die Identifizierung von (natürlichen und künstlichen) Deformationsmechanismen durch mikrostrukturelle Analysen. Obwohl die Gesteine auf einer Skala von 10 bis $100 \mathrm{~m}$ recht homogen zu sein schienen, zeigten die Ergebnisse deutliche strukturelle und sedimentäre Heterogenitäten auf der Meter-Skala, die die Bruchdichte beeinflussen.

Ein weiteres in Süddeutschland gelegenes Teilgebiet beherbergt den Opalinuston (OPA). Diese bis zu $150 \mathrm{~m}$ dicke Tonsteinformation wurde im Mitteljura abgelagert (Franz and Nitsch, 2009). Aufgrund seiner selbstabdichtenden Eigenschaften und seiner Fähigkeit Fluide zurückzuhalten soll er das Atommülllager der Schweiz beherbergen (Bossart et al., 2017). Der OPA ist hinsichtlich seiner Lithologie und (Bio-)Stratigraphie recht gut erforscht. Darüber hinaus wurden mineralogische, hydrologische und petrophysikalische Untersuchungen durchgeführt, die zum größten Teil in Hochschularbeiten dokumentiert sind, die einige Jahrzehnte alt und manchmal schwer zugänglich sind. Es ist jedoch fraglich, inwieweit diese Untersuchungen die Situation in den für das Standortauswahlverfahren relevanten Tiefen widerspiegeln. Gut dokumentierte Daten zum OPA und seinen für die nukleare Entsorgung relevanten Eigenschaften sind über das Schweizer Standortauswahlverfahren verfügbar (Bossart et al., 2017). Da jedoch noch erhebliche Fragen zur Beschaffenheit (z.B. räumliche Verteilung der Lithologie, Mineralogie, Mikrostrukturen) der in Deutschland gelegenen Bereiche des OPA in Tiefen größer als einige Dekameter bestehen, ist es schwer abzuschätzen, inwieweit die im Schweizer Standortauswahlverfahren gewonnenen Erkenntnisse sich auf Deutschland übertragen lassen. Daher zielt die 2020 begonnene Phase II von BASTION darauf ab, den in Phase I entwickelten multidisziplinären Ansatz zu nutzen, um die für die sichere Langzeitlagerung von Atommüll relevanten Eigenschaften des OPA durch Identifizierung und Quantifizierung struktureller und rheologischer Heterogenitäten zu charakterisieren. Dies wird eine wichtige Grundlage für numerische Modelle zur Bewertung der langfristigen Sicherheit darstellen.

\section{References}

BGE - Bundesgesellschaft für Endlagerung: Zwischenbericht Teilgebiete gemäß $\S 13$ StandAG, Stand 28. September 2020, Geschäftszeichen: SG01101/16-1/2-2019\#3, 2020.

Bossart, P., Bernier, F., Birkholzer, J., Bruggeman, C., Conolly, P., Dewonck, S., Fukava, M., Herfort, M., Jensen, M., Matray, J.-M., Mayor, J. C., Moeri, A., Oyama, T., Schuster, K., Shigeta, N., Vietor, T., and Wiczorek, K.: Mont Terri rock laboratory, 20 years of research: introduction, site characteristics and overview of experiments, Swiss J. Geosci., 110, 3-22, https://doi.org/10.1007/s00015-016-0236-1, 2017.

Franz, M. and Nitsch, E.: Zur lithostratigraphischen Gliederung des Aalenium in Baden-Württemberg, LGBR-Informationen, 22, 123-146, 2009.

StandAG - Standortauswahlgesetz: Standortauswahlgesetz vom 5. Mai 2017 (BGBl. I S. 1074), das zuletzt durch Artikel 247 der Verordnung vom 19. Juni 2020 (BGB1. I S. 1328) geändert worden ist, 2017. 